\title{
REVIEWARTICLE
}

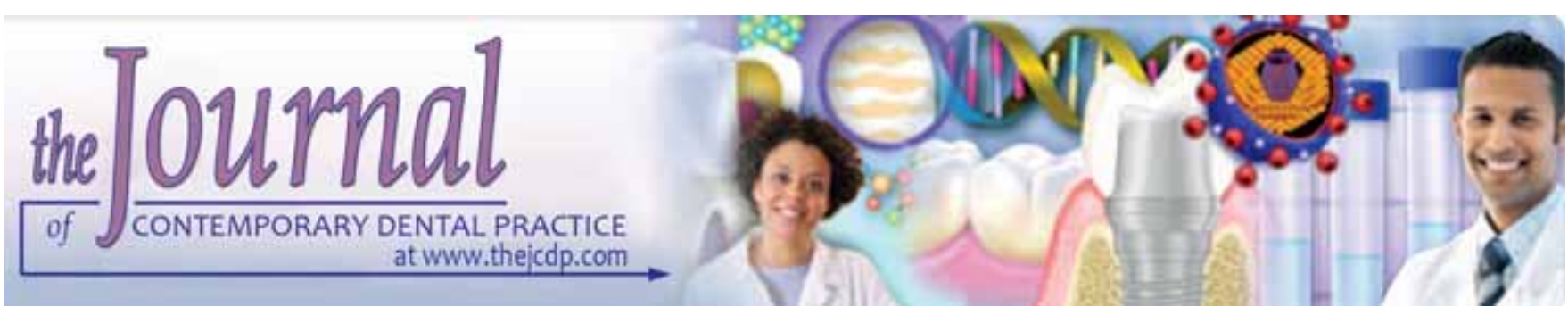

\section{Functional and Esthetic Rehabilitation with In-Ceram Alumina and Zirconia System: A Multidisciplinary Approach}

Adriana Cristina Zavanelli, José Vitor Quinelli Mazaro, Sandra Rahal Mestrener, Recardo Alexandre Zavanelli

\begin{abstract}
The development of all-ceramic systems following metalceramics restorations allowed simulation of natural dentition due to favorable esthetics and resistance. In-Ceram is an alternative when esthetics is primordial as well as resistance required in rehabilitation. However, an ideal smile is associated to not only shape, color, texture and translucency but also harmony with gingival tissue. So, the aim of this study is to report a clinical case based on periodontal and fixed partial dentures principles to perform periodontal plastic surgery followed by esthetic rehabilitation. A female patient, 40-year-old, presented complaint about dental esthetics. After clinical and radiographic exams, metal-ceramics crowns (teeth 11, 12, 13, 21, 22 and 23) were considered unsatisfactory due to marginal leakage, color change in gingival tissue associated to metallic margin, and gummy smile. So, a crown lengthening surgery of anterior teeth was performed followed by rehabilitation of superior teeth with InCeram single crowns.
\end{abstract}

Clinical significance: The interaction between periodontics and fixed prosthodontic area is the key of an adequated treatment planning which involves gingival smile to provide function and an esthetic condition in association with an esthetic, resistant and predictable material.

Keywords: All-Ceramic, Fixed partial denture, Crown lengthening surgery.

How to cite this article: Zavanelli AC, Mazaro JVQ, Mestrener SR, Zavanelli RA. Functional and Esthetic Rehabilitation with In-Ceram Alumina and Zirconia System: A Multidisciplinary Approach. J Contemp Dent Pract 2011;12(1):68-72.

Source of support: Nil

Conflict of interest: None declared

\section{INTRODUCTION}

The demand for tooth-colored restorations has grown considerably during the last decade. ${ }^{3}$ All-ceramic systems became a viable treatment option with successful use in the anterior and posterior segments ${ }^{25,10}$ as result of advanced dental technology and high-strength ceramic materials. Such restorative all-ceramic systems must fulfill biomechanical requirements and provide longevity similar to metal-ceramic restorations ${ }^{7,9}$ while providing enhanced esthetics. ${ }^{26}$

Ceramics are widely used in dentistry. The association of ceramics to metallic structures represents a safe technique with adequate longevity.

The popularity of metal-ceramic restorations results from predictable strength with reasonable esthetics. The esthetic appearance of a metal-ceramic restoration is related to margin design (porcelain butt margin with a vertical cut back), metallic alloy, and skill of the ceramist. ${ }^{22}$ The disadvantage of such restorations is increased light reflectivity since the opaque porcelain masks the metallic substrate. ${ }^{20}$ The natural tooth allows light transmission while a metal-ceramic restoration just allows light reflection. So, all-ceramic restorations are an alternative to achieve translucency in esthetics similar to natural teeth. ${ }^{13,19}$

Ceramic translucency can be affected by many factors, including thickness, ${ }^{1,15}$ microstructure and number of firing cycles. ${ }^{21}$

The term 'In-Ceram' derives from "ceramic infiltration”. In-Ceram system is classified as infiltrated ceramic indicated to obtain frameworks of crowns and fixed partial dentures with high strength - three more times than feldspathic ceramics-to receive veneering ceramic. ${ }^{12}$ In-Ceram technique was developed by a French scientist named Dr. M Sadoun and it was introduced in market by VITA in 1989. Initially, the system presented three different materials: Alumina, spinel and zirconia.

The gummy smile is a common esthetic complaint. This smile design is defined as a gingival exposure superior to $3 \mathrm{~mm}$ during a moderate smile ${ }^{3}$ and the etiology is related to different factors as altered passive eruption, ${ }^{14}$ increased gingival volume due to plaque or medicine, ${ }^{3}$ and vertical maxillary excess. ${ }^{14,11}$ So, the present clinical case reports the treatment planning for a patient with gummy smile resulted from altered passive eruption and bacterial plaque due to difficult hygiene. 
The purpose of this study is to demonstrate the viability of In-Ceram system in a clinical case based on periodontal and fixed partial denture principles to perform periodontal plastic surgery followed by esthetic rehabilitation.

\section{CLINICAL REPORT}

A female patient, 40-year-old with concern about dental appearance presented for treatment in Clinic of Prosthodontics Specialization of Araçatuba Dental SchoolUNESP. After clinical and radiographic exams, metalceramics crowns (teeth 11, 12, 13, 21, 22 and 23) were considered unsatisfactory with marginal leakage, color change in gingival tissues due to metallic margins, and gummy smile resulted from altered passive eruption (Fig. 1). Considering the unsatisfactory characteristics and esthetic requirement, an apically repositioned flap surgery with osteotomy was performed since the bone level was in the cementoenamel junction. Thus, the maxillary arch was restored with In-Ceram single crowns. The anterior crowns were fabricated with In-Ceram alumina and the posteriors with zirconia. Initially, a crown lengthening surgery combining gingivectomy and osteotomy was performed (Figs 2 and 3). The teeth 11, 12, 15, 16, 21, 22, 23 and 26 presented coronary destruction and required restoration with metallic cast posts. According to indirect technique, the root canal was prepared with largo followed by impression with polyether (Impregum Soft, Espe, EUA) using syringe and individual tray. The master cast was obtained by pouring of dental stone type IV. The casts were placed in articulator to wax the coronary portion cast post and core system according to antagonist teeth. The tooth 16 received a 2pieces cast core with attachment system due to diverging roots. Following cementation with zinc phosphate cement, teeth were prepared to fabricate the prostheses. Teeth 11, 12, 13, 21, 22 and 23 were restored with In-Ceram alumina crowns while teeth 14, 15, 16, 17, 24, 25 and 26 received In-Ceram zirconia restorations. Teeth were prepared according to the following principles: Preparation preserving dental anatomy, incisal and occlusal preparation extend from 1.5 to $2.0 \mathrm{~mm}$, axial preparation extend of $1.2 \mathrm{~mm}$, rounded internal angles, conical axial walls, marginal design in rounded shoulder or extended chamfer (Fig. 4). After this phase, impression with alginate (Hydrogum, Zhermack, Italy) was performed to evaluate parallelism in retainer teeth and final characteristics of tooth preparation and confection of provisional crowns (Fig. 5). Individual coping in acrylic resin were fabricated and relined with red acrylic resin (Duralay, Reliance Dental Mfg Co, USA). Adhesive to impression material was applied in the internal surface of acrylic resin copings and $2 \mathrm{~mm}$ externally to the margin following 5 minutes to dry. Polyether Impregum was

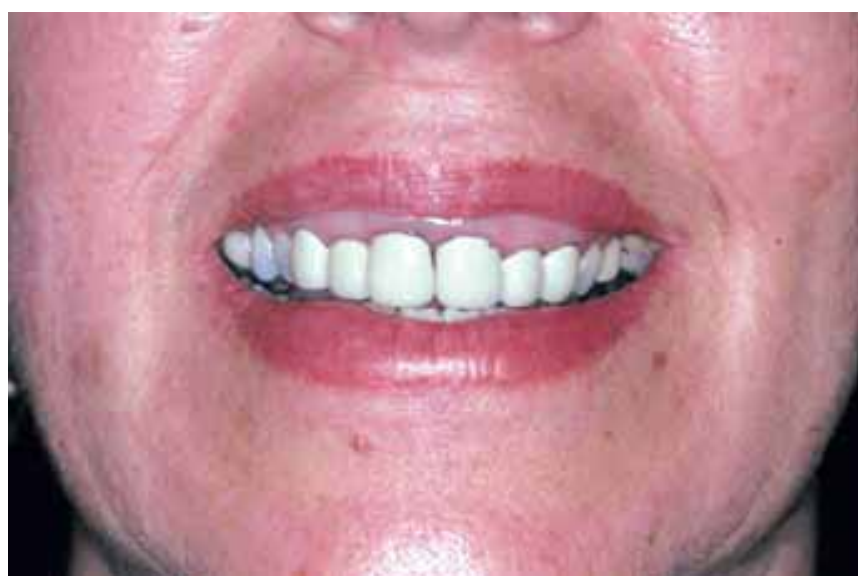

Fig. 1: Initial smile appearance

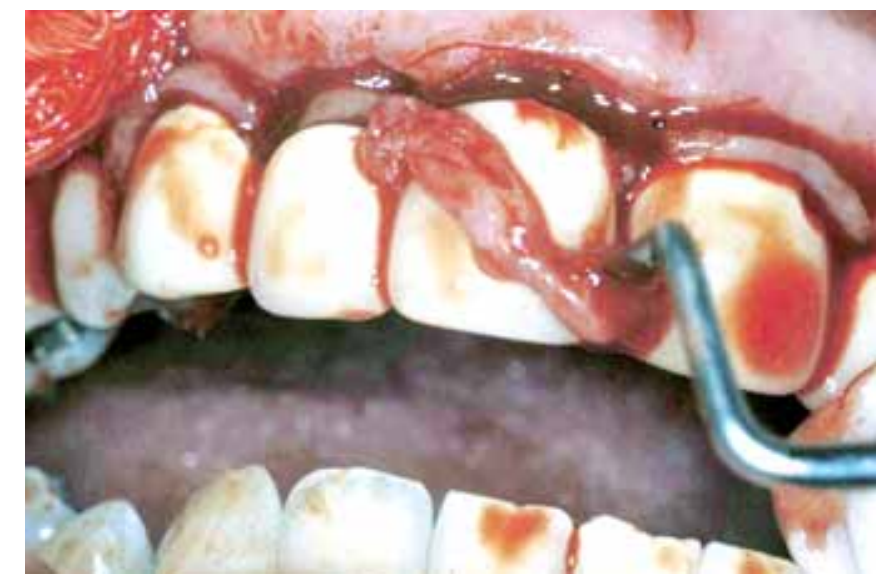

Fig. 2: Gingival collar removal between teeth 13 and 23 following anterior incision

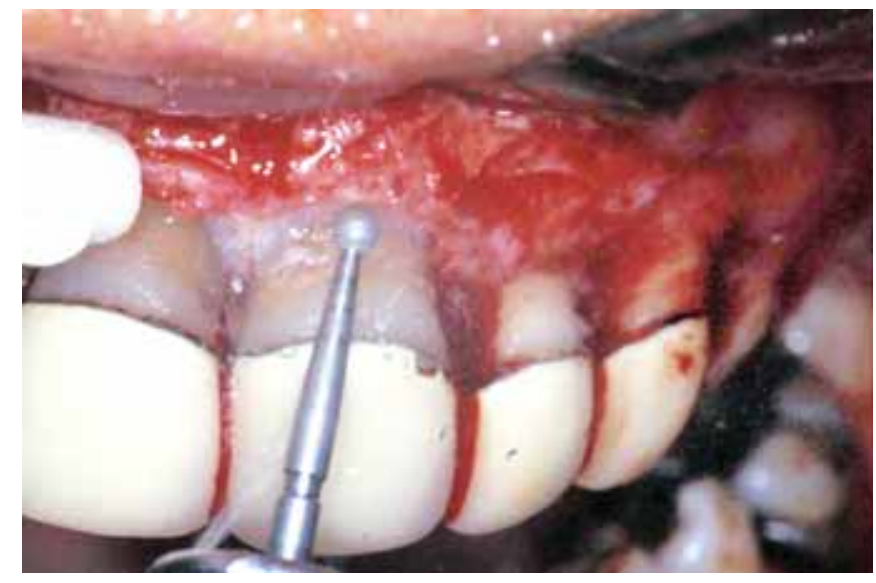

Fig. 3: Osteotomy

manipulated on a glass plate according to manufacturer's instructions. The acrylic resin copings were filled with impression material and slowly positioned on tooth. After polymerization, the acrylic resin copings were removed with an individual tray filled with Impregum (Fig. 6). Provisional crowns were placed until fabrication of copings (Fig. 7). The copings were proven to evaluate fit and interocclusal space available to porcelain (Fig. 8). The 
ceramic copings are opaque and may recover metallic cores with esthetic damage. Definitive crowns were proven and cemented with zinc phosphate cement (SS White, USA) (Fig. 9).

\section{DISCUSSION}

The gummy smile was corrected through an apically repositioned flap surgery with osteotomy to achieve satisfactory esthetic result. Esthetic periodontal surgeries aim to correct quantity, contour and design of gingival tissue. Some factors are relevant to indicate esthetic periodontal surgeries such as localization of gingival margin in relation to cementoenamel junction and quantity of keratinized gingiva. Crown lengthening may increase interdental space and create "the black hole". Some authors suggest a labial flap with preservation of interdental bone to avoid this effect. So, the crown length is increased with maintenance of interdental gingiva level. ${ }^{6}$

In-Ceram system presents some advantages as more favorable esthetics than metal-ceramic restorations, decreased thermal sensibility, higher flexure strength than dentin and enamel, biocompatibility, surface that avoids bacterial plaque, high functional strength (favorable to anterior crowns and bridges), and high perioprosthetic value. Furthermore, the system exhibits low degree of thermal

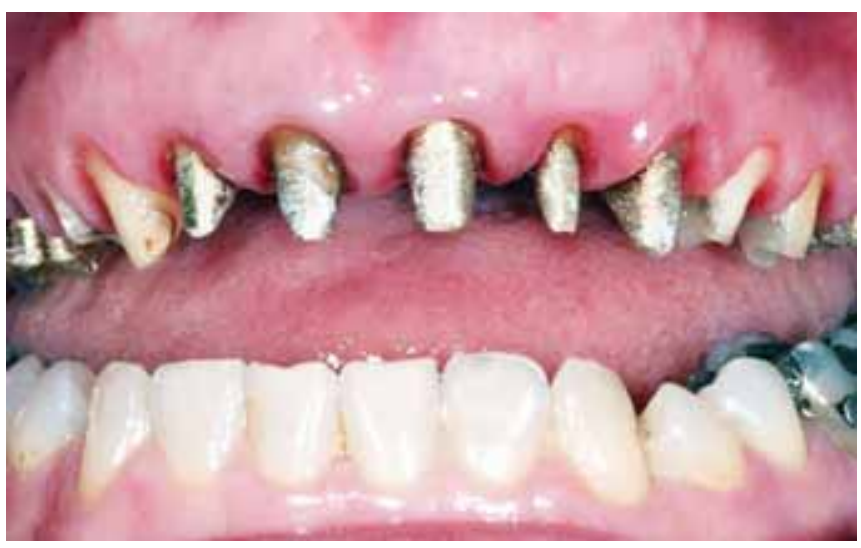

Fig. 4: Frontal view of prepared teeth

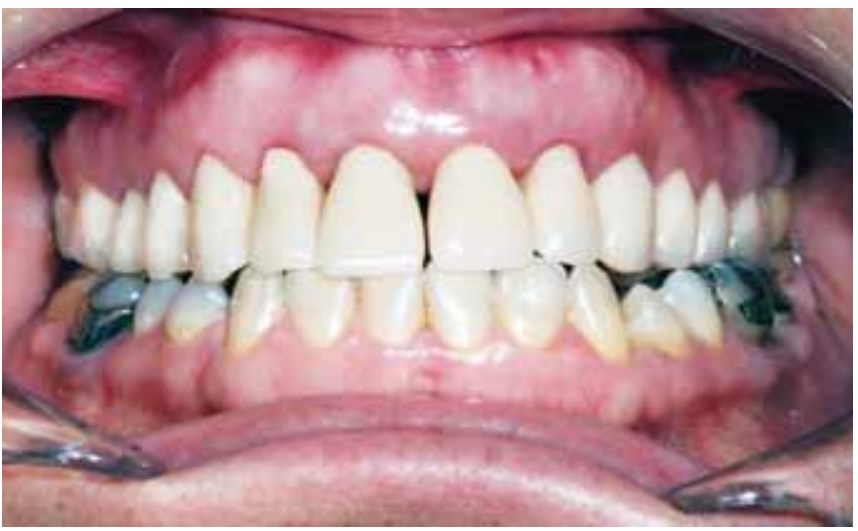

Fig. 5: Aspect of the provisional restorations installed

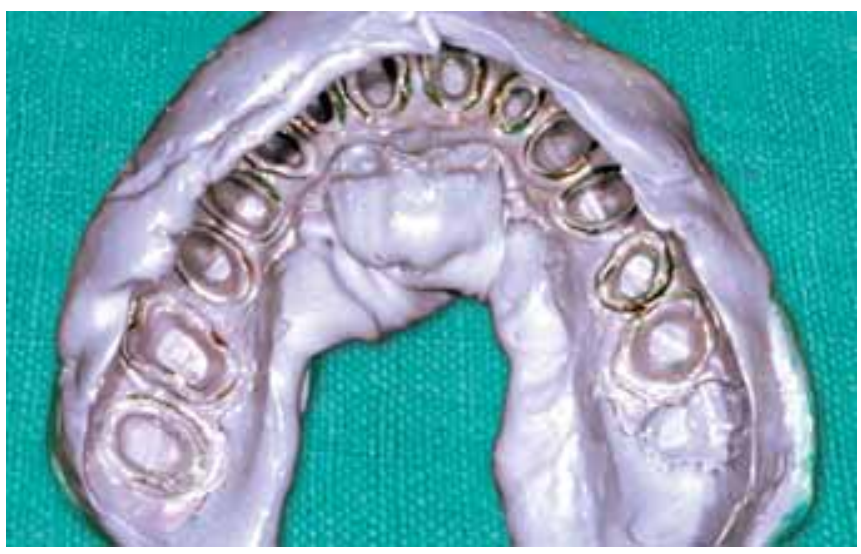

Fig. 6: Impression

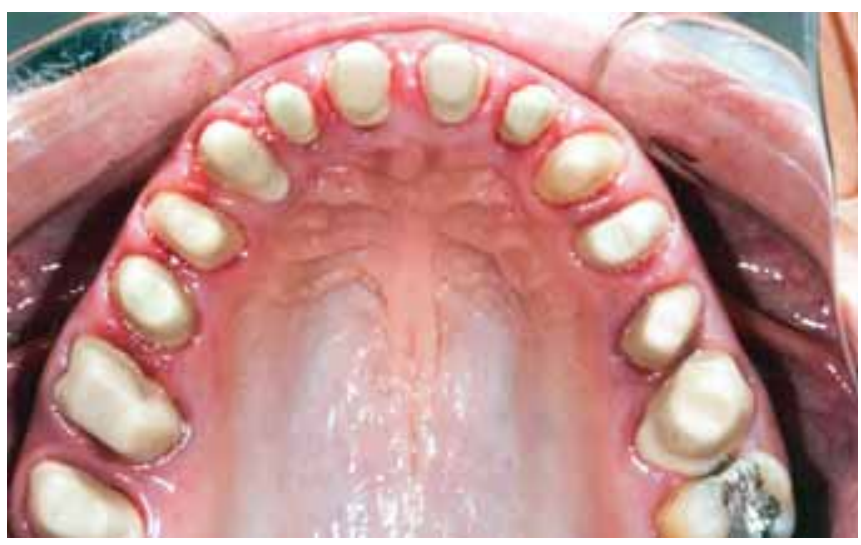

Fig. 7: Occlusal view of proof of ceramic copings

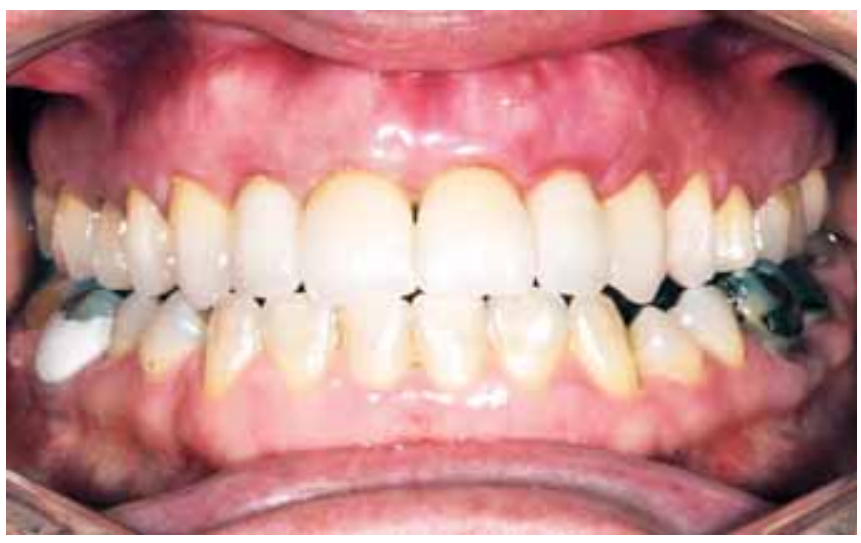

Fig. 8: Proof of definitive crowns

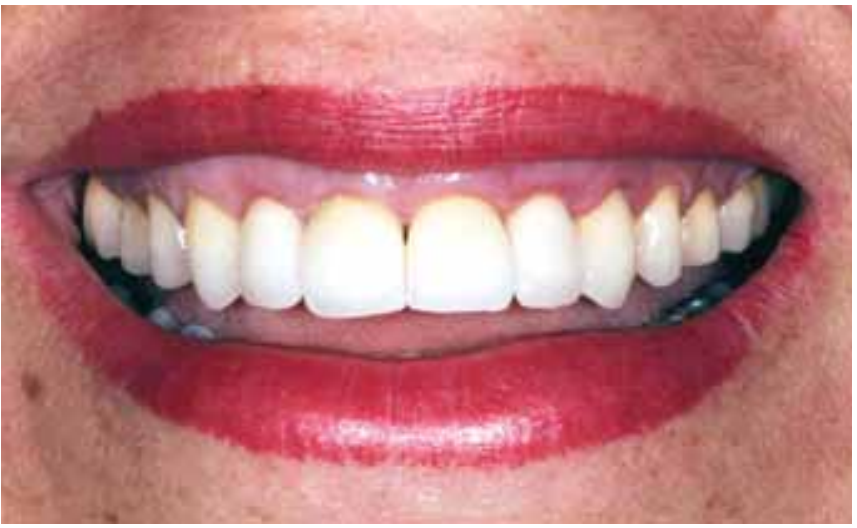

Fig. 9: Finished clinical case 
conductivity, all phases are laboratorial (decreased risks and quality control), there is no interface between metal and ceramic, and the material presents radiographic translucency and low weight. So, In-Ceram is indicated to anterior and posterior teeth even when there is color change or metallic core due to opacity. However, the system is counterindicated when patient presents bruxism or inadequate space for occlusal adjustment $(1.5 \mathrm{~mm}$ in occlusal surface and $1.2 \mathrm{~mm}$ in axial walls). ${ }^{17}$

In-Ceram alumina is indicated to anterior and posterior single crowns or anterior 3-unit fixed prostheses when maximum translucency is required. ${ }^{24}$

In-Ceram zirconia is a ceramic reinforced with zircon oxide, and it presents higher flexure strength than In-Ceram alumina and spinell. ${ }^{5}$

Longitudinal studies confirmed the excellent clinical performance of prostheses fabricated with In-Ceram ${ }^{12}$ with mean values of annual failures between 0.3 and $1.6 \%{ }^{2}$

Color of coping is an important esthetic factor. The correct color selection for coping allows better simulation of chromatic characteristics and translucency of natural tooth. ${ }^{8}$ In addition, increased thickness of framework results in reduced space for ceramic and increased opacity, which influences restoration esthetics.

The treatment prognostic with In-Ceram restorations depends on tooth preparation. The preparation configuration is directly related to thickness of final restoration that, without metal, must respect physical properties and characteristics of ceramics. So, the restorations may distribute the load generated during mastication.

The correct selection of cement is important for prostheses longevity since materials present different clinical performance.

Resin cements used in conjunction with adhesive systems have been shown to significantly improve the fracture resistance, biaxial flexural strength, and microleakage of glass-ceramic-based all-ceramic restorations in vitro. ${ }^{23,4}$

Zinc phosphate cement and resin cements are indicated for In-Ceram system. The resin cements can be associated to specific treatments of internal surface of crowns. ${ }^{16,18}$

\section{CONCLUSION}

In-Ceram system is a restorative alternative with functional and esthetic indication for different cases scientifically evaluated. The system presents several indications, including fixed dentures, with advantages regarding clinical, biological and scientific factors. Clinical performances with In-Ceram are over 12 years which represents safety during appliance.

The treatment in the present study restored esthetics, function, phonetics, comfort and oral health. According to literature, it can be concluded that planning involving different specialties in dentistry results in function restoration and esthetics maximization.

\section{REFERENCES}

1. Antonson SA, Anusavice KJ. Contrast ratio of veneering and core ceramics as a function of thickness. Int J Prosthodont 2001;14:316-20.

2. Bindl A, Mormann WH. An up to 5-year clinical evaluation of posterior In-Ceram CAD-CAM core crowns. Int J Prosthodont 2002;15:451-56.

3. Burke FJ, Fleming GJ, Nathanson D, Marquis PM. Are adhesive technologies needed to support ceramics? An assessment of the current evidence. J Adhes Dent 2002;4:7-22.

4. Chong KH, Chai J, Takahashi Y, Wozniak W. Flexural strength of In-Ceram alumina and In-Ceram zirconia core materials. Int J Prosthodont 2002;15:183-88.

5. Denry IL, Holloway JA, Rosenstiel SF. Effect of ion exchange on the microstructure, strength, and thermal expansion behavior of a leucitereinforced porcelain. J Dent Res 1998;77:583-88.

6. Devigus A, Lombardi G. Shading Vita In-Ceram YZ substructures; influence on value and choroma, (Part II). Int J Comput Dent 2004;7:379-88.

7. Drummond JL. Ceramic behavior under different environmental and loading conditions. In: Eliades G, Eliades T, Brantley WA, Watts DC (Eds). Dental materials in vivo: Aging and related phenomena. Chicago: Quintessence 2003:35-45.

8. Fradeani M, D’Amelio M, Redemagni M, Corrado M. Fiveyear follow-up with Procera all-ceramic crowns. Quintessence Int 2005;36:105-13.

9. Giordano RA. A comparison of all-ceramic restorative systems (Part 2). Gen Dent 2000;48:38-40.

10. Giordano RA. Dental ceramic restorative systems. Compend Contin Educ Dent 1996;17:779-82.

11. Heffernan MJ, Aquilino SA, Diaz-Arnold AM, Haselton DR, Stanford CM, Vargas MA. Relative translucency of six allceramic systems (Part I): Core materials. J Prosthet Dent 2002;88:4-9.

12. Huls A. All ceramic restaurations with the In-Ceram system: 6 years of clinical experience. A short manual. Vita 1995:10-11.

13. Kelly JR, Nishimura I, Campbell SD. Ceramics in dentistry: Historial roots and current perspectives. J Prosthet Dent 1996;75:18-32.

14. Kern M, Strub JR. Bonding to alumina ceramic in restorative dentistry: Clinical results over up to 5 years. J Dent 1998;26: 245-49.

15. McLean JW, Hubbard JR, Kedge MI. Science and art of dental ceramics. Chicago: Quintessence 1979:333.

16. Mclean JW. Newdental ceramics and esthetics. J Esthet Dent 1995;7:141-49.

17. Mcleam JW. Evolution of dental ceramics in the twentieth century. J Prosthet Dent 2001;85:61-66. Review. Erratum in: J Prosthet Dent 2001;85.

18. O’Brien WJ, Johnston WM, Fanian F. Double-layer color effects in porcelain systems. J Dent Res 1985;64:940-43.

19. Pagniano RP, Seghi RR, Rosenstiel SF, Wang R, Katsube N. The effect of a layer of resin luting agent on the biaxial flexure strength of two all-ceramic systems. J Prosthet Dent 2005;93:459-66. 
20. Paul SJ, Pietrobon N, Schaere P. The new In-Ceram Spinell system-a case report. Int J Periodontics. Restorative Dent 1995;15:521-27.

21. Probster L. Four-year clinical study of glass-infiltrated, sintered alumina crowns. J Oral Rehabil 1996;23:147-51.

22. Raigrodski AJ, Chiche GJ. The safety and efficacy of anterior ceramic fixed partial dentures: A review of the literature. J Prosthet Dent 2001;86:520-25.

23. Richard VN. Introduction to dental materials (2nd ed). St Louis: Elsevier 2002:235-36.

24. Sorensen JA. In-Ceram fixed partial dentures: Three-year clinical trial results. CDA J 1998;26:207-04.

25. Sorensen JA, Knode H, Torres TJ. In-Ceram all-ceramic bridge technology. Quintessence Dent Technol 1992:41-46.

26. Stavridakis MM, Krejci I, Magne P. Immediate dentin sealing of onlay preparations: Thickness of pre-cured dentin bonding agent and effect of surface cleaning. Oper Dent 2005;6: 747-57.

\section{ABOUT THE AUTHORS}

\section{Adriana Cristina Zavanelli}

Associate Professor, Department of Dental Materials and Prosthodontics, FOA-UNESP, São Paulo, Brazil

\section{José Vitor Quinelli Mazaro}

Associate Professor, Department of Dental Materials and Prosthodontics, FOA-UNESP, São Paulo, Brazil

\section{Sandra Rahal Mestrener}

Associate Professor, Department of Restorative Dentistry FOA-UNESP, São Paulo, Brazil

\section{Recardo Alexandre Zavanelli (Corresponding Author)}

Avenida Dep. Jamel Cecilio, 2496, Jardim Goiás 74810-100, GoiâniaGoiás-Brazil, Phone: +5562-30883820, e-mail: ricardozavanelli@ hotmail.com 